\title{
A Case with Chickenpox and Epididymoorchitis: More Than a Coincidence?
}

\section{Epididimoorşitle Seyreden Bir Suçiçeği Olgusu, Bir Tesadüften Fazlası mı?}

\author{
Gökçe Celep ', Kenan Varol², Yalçıner Erdoğan', Ramazan Uyar', Bilge Akman Kahraman'1, Ayla Güven³ \\ ${ }^{1}$ Clinic of Pediatrics, Amasya Sabuncuoglu Serefeddin Training and Research Hospital, Amasya, Turkey \\ ${ }^{2}$ Clinic of Radiology, Amasya Sabuncuoglu Serefeddin Training and Research Hospital, Amasya, Turkey \\ ${ }^{3}$ Health Sciences University, Zeynep Kamil Women and Children Diseases Training and Research Hospital, Istanbul, Turkey
}

Cite this article as: Celep G, Varol K, Erdoğan Y, Uyar R, Akman Kahraman B, Güven A. A case with chickenpox and epididymoorchitis: more than a coincidence? J Pediatr Inf 2019;13(2):e88-e91

Abstract

Varicella infection (chickenpox) is a benign and self- limited exanthematous, contagious childhood disease. Secondary bacterial infections, neurological problems, pneumonia and hematologic involvement are frequent and well known complications. Epididymoorchitis, the inflammation of the epididymis and testicles, is a rare and unknown complication of varicella. Here, a five- year old boy with varicella infection complicated with epididymoorchitis is presented. He was admitted to our hospital on the seventh day of the vesiculopustular rash of chickenpox with scrotal induration. By the help of scrotal Doppler ultrasonography epididymoorchitis was diagnosed. He was hospitalized for antimicrobial and supportive treatment and on the sixth day discharged in good condition with oral treatment. We would like to draw attention to the rare complications of frequent illnesses. Varicella infection with epididymoorchitis is a rare, but a preventable problem.

Keywords: Chickenpox, epididymoorchitis, acute scrotum, rare complication, vaccination
Öz

Varisella enfeksiyonu (suçiçeği), döküntülü, genellikle kendini sınırlayabilen, bulaşıcı bir çocukluk hastalığıdır. Sekonder bakteriyel enfeksiyonlar, nörolojik sorunlar, pnömoni ve hematolojik tutulum ise iyi bilinen komplikasyonlarıdır. Epididimoorşit, epididim ve testislerin iltihabı, nadir ve bilinmeyen bir suçiçeği komplikasyonudur. Burada, epididimoorşit ile komplike suçiçeği enfeksiyonu geçiren beş yaşında bir erkek hasta sunulmaktadır. Hastanemize vezikülopüstüler suçiçeği döküntüsünün yedinci gününde skrotumda şişlik nedeniyle başvuran hastaya skrotal Doppler ultrasonografi ile epididimoorşit tanısı konulmuştur. Antimikrobiyal ve destekleyici tedavi için hastaneye yatırılıp, altıncı günde genel durumu iyi olarak oral tedaviye devam etmek üzere taburcu edilmiştir. Bu olgu sunumu ile sık görülen hastalıkların nadir komplikasyonları olabileceğine dikkat çekmek istenmiştir. Epididimoorşit ile varisella enfeksiyonu nadir; fakat önlenebilir bir problemdir.

Anahtar Kelimeler: Suçiçeği, epididimoorşit, akut skrotum, nadir komplikasyon, bağışıklama

Correspondence Address / Yazışma Adresi

\section{Gökçe Celep}

Amasya Sabuncuoğlu Şerefeddin Devlet Hastanesi, Çocuk Sağlığı ve Hastalıkları Kliniği,

Amasya-Türkiye

E-mail: gokce4celep@yahoo.com 


\section{Introduction}

Varicella is usually a self-limiting infectious disease, but sometimes it can result in complications that are potentially serious $(1,2)$. Most hospitalizations for varicella occur in children who are previously healthy and complications can affect both immunocompetent and immunocompromised children $(1,2)$.

Epididymoorchitis is the inflammation of the epididymis and testicles. It is one of the most common reasons of acute scrotum in prepubertal boys (3). The differential diagnosis of the acute swollen scrotum other than epididymoorchitis, includes torsion of the testicles, incarcerated hernia, edema of the scrotum, testicular tumor and trauma which are also emergent problems (3). Epididymoorchitis can be the manifestation of a systemic bacterial or viral infection, the result of genitourinary abnormalities or trauma (3). Infectious agents vary with patients' age and sexual activity, but in prepubertal boys aerobic bacteria and viruses are common (3). Epididymoorchitis is rarely reported as a chickenpox complication in literature. We would like to draw attention to this rare complication of varicella which can be due to the primary viral involvement or secondary bacterial infection.

\section{Case Report}

A five-year old boy was admitted to our hospital with the complaints of fever $\left(>38.5^{\circ} \mathrm{C}\right.$, axillary), left testicular pain and swelling. Seven days before the admission, typical vesiculopustular lesions of varicella were noticed on his trunk and clinically he was diagnosed as chickenpox. Meanwhile constitutional symptoms such as fever, malaise and lower abdominal pain developed with bilateral scrotal tenderness and erythema (Figure1). There was no history of testicular trauma or operation. He didin't experience dysuria, urgency, frequency, nausea, vomiting, change in the smell and colour of the urine; symptoms of urinary tract infection. His sexual development was prepubertal. Physical examination revealed bilateral scrotal erythema with an enlarged scrotum. The clinical findings were more prominent in the left scrotum. There were not any signs of costovertebral angle and suprapubic region tenderness; the scrotum was tender by palpation. The cremasteric reflex was examined by stroking the skin of upper medial thigh and bilateral elevation of testicles were observed with the cremasteric muscle contraction and this was evaluated as "normal". Laboratory investigations were not notable except mild decrease in blood urea nitrogen $14 \mathrm{mg} / \mathrm{dL}$ (16.6-48.5 mg/ $\mathrm{dL}$ ). Blood leukocyte count was $6.570 / \mathrm{mm}^{3}$, with $28.9 \%$ neutrophils, $54.4 \%$ lymphocytes, and $14.8 \%$ monocytes. Hepatic enzymes and serum amylase concentrations were normal. C-reactive protein (CRP) level was high, $27.4 \mathrm{mg} / \mathrm{L}(0-5 \mathrm{mg} / \mathrm{L})$. The urinalysis revealed no chemical or microscopic abnormal-

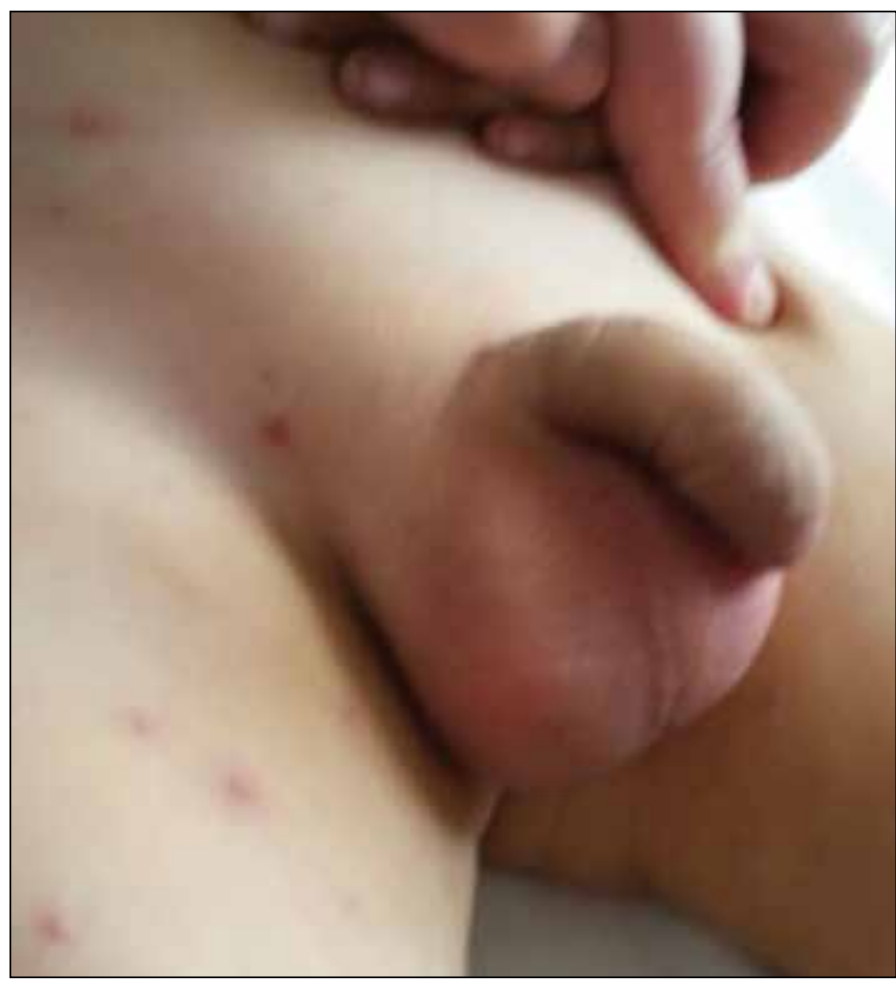

Figure 1. The vesiculopustules and induration of the scrotum, prominent on the left side.

ities. The urine culture was sterile. Scrotal Doppler ultrasonography was performed and vascular activity in both testicles and epididymis was remarkable, pointing epididymoorchitis. Bilateral tunica vaginalis was thickened and edematous in appearance. The left scrotum showed multiloculated thickened fluid suggesting complicated hydrocele. The scrotal skin thickness was slightly increased with edema referring cellulite. Testicular torsion, the most important differential diagnosis, was ruled out. The hydrocele fluid was not suitable for obtaining laboratory specimen and punctuation was not offered for children in the literature, so this invasive process was disregarded. The patient was hospitalized for treatment. Bed rest and scrotal elevation were provided. Intravenous sulbactam-ampicillin, acyclovir, a non-steroidal anti-inflammatory agent were selected as drug therapy. Pediatric surgery consultation was asked for further evaluation and our therapy was confirmed as appropriate. The patient'shigh fever $\left(>38.5^{\circ} \mathrm{C}\right)$ present throughout the first two days of his hospitalization resolved and epididymoorchitis retrograded clinically. CRP level decreased to $8 \mathrm{mg} / \mathrm{L}$. The patient was discharged on the sixth day of hospitalization with oral amoxicillin clavulanate. He was in good condition at his first-week visit. There was no sign of scrotal induration and tenderness; the testicles were in the scrotum chickenpox lesions were healing. Scrotal Doppler ultrasonography was performed and showed that bilateral testicular, epididymal vascular activity and testicular volumes 
were normal. When compared with the previous examination, regression was detected.

\section{Discussion}

Here, a five -year- old boy with epididymoorchitis and chickenpox, which is a rare complication of varicella infection, is presented. Varicella is a usually benign and self- limiting infectious disease, but sometimes, it can result in complications that are potentially serious and require hospitalization, including secondary bacterial infections (mainly of the skin and skin structures), respiratory complications (pneumonia), hematologic changes and neurological problems (encephalitis and cerebellitis) $(1,2)$. Varicella can be fatal in immunsupressive children; a review of the literature revealed that disseminated intravascular coagulopathy can be the cause of death in immunocompromised patients with chickenpox infection (4).

In infants, epididymoorchitis can be a manifestation of a systemic disease or can be associated with an underlying genitourinary abnormality. However, this is a controversial problem in prepubertal boys. The causes of epididymoorchitis in prepubertal boys are infectious agents (bacterial, viral, fungal), genitourinary tract abnormalities, postinfectious inflammatory reactions, vasculitides, certain medications or local trauma $(3,5)$. In patients with epididymoorchitis, urine cultures correlate well with epididymal aspirates, so especially in children aspiration is not recommended, urine is sufficient for laboratory investigations. Unfortunately, we do not have the chance of polymerase chain reaction (PCR) for varicella, but the urine culture of the patient was sterile. Mumps is the most frequent viral infection causing epididymoorchitis. Enteroviruses, adenoviruses, influenza cytomegalovirus, and many other viruses have been reported (3). Varicella is a rare reason for epididymoorchitis. It is not well known whether it occurs as a result of primary viral involvement, postinfectious inflammatory reactions or secondary bacterial infection of the varicella vesicles. Postinfectious inflammatory reactions are not common in children (6). Extensively evaluation of the literature we have identified that epididiymoorchitis linked to varicella had only been described in nine cases (7-13) (Table1). The ages of the patients were between 2 and 46. In all patients, epididymoorchitis appeared within ten days as it is in this case, after the onset of rash. Symptomatic treatment with bed rest and scrotal elevation was offered. Antibiotics and surgical decompression were other treatment methods, usually related with other complications $(9,11)$. Partial and complete atrophy were reported in the patients who had severe disease with pneumonia and neurologic involvement $(10,11)$. Our patient was also treated with bed rest and scrotal elevation with sulbactam-ampicillin, acyclovir as parenteral antimicrobial therapy and discharged with oral amoxicillin-clavulunate (1). The long term outcome of varicella infection with epididymoorchitis is not well known, more case reports with long term follow up will be able to give us information about this complication. Our patient continues to be evaluated during well child visits periodically.

Varicella is a rare, but preventable reason for epididymoorchitis. Vaccination can prevent most of these complications and is offered for all children over one year old (2). It was added to our national vaccination schedule in December 2012. Universal vaccination seems to be the only realistic option for preventing severe complications. In conclusion, we presented this case report to draw attention to this rare and unknown, preventable complication of varicella.

Table 1. Summary of varicella related epididymoorchitis cases in the literature

\begin{tabular}{|c|c|c|c|c|}
\hline Author & $\begin{array}{c}\text { Age of the case } \\
\text { (years) }\end{array}$ & $\begin{array}{l}\text { Days of the rash before } \\
\text { epididymoorchitis }\end{array}$ & Testes involved & Follow up \\
\hline Sebrazes J. 1927 (7) & 20 & 1 & Both & Unknown \\
\hline Wesselhoeft C, Pearson CM. 1950 (11) & 46 & 9 & Right & $\begin{array}{l}\text { Partial atrophy, } \\
6 \text { months }\end{array}$ \\
\hline Ormiston G. 1953 (12) & 7 & 5 & Left & $\begin{array}{l}\text { Complete atrophy, } \\
6 \text { months }\end{array}$ \\
\hline Turner RB. 1987 (13) & 14 & 2 & Right & $\begin{array}{l}\text { No atrophy, } \\
2 \text { months }\end{array}$ \\
\hline Hunt MNS. 1990 (9) & 2 & 4 & Left & $\begin{array}{l}\text { No atrophy, } \\
1 \text { week }\end{array}$ \\
\hline $\begin{array}{l}\text { Liu HC et al. } 1994 \text { (10) } \\
\text { ( } 2 \text { cases) }\end{array}$ & $\begin{array}{l}2 \\
5\end{array}$ & $\begin{array}{l}3 \\
4\end{array}$ & $\begin{array}{l}\text { Right } \\
\text { Left }\end{array}$ & $\begin{array}{l}\text { No atrophy, } 22 \text { months } \\
\text { No atrophy, } 2 \text { months }\end{array}$ \\
\hline Kaul A et al. 2012 (8) & \multicolumn{4}{|c|}{$\begin{array}{l}\text { Two cases after the history of renal transplantation, clinical features are not mentioned, treated with } \\
\text { acyclovir }\end{array}$} \\
\hline Our case & 5 & 7 & Both, left prominent & No atrophy, 3 weeks \\
\hline
\end{tabular}


Informed Consent: Written consent was obtained from the parents of the patient.

Peer-review: Externally peer-reviewed.

Author Contributions: Concept - GC, AG; Design - GC, AG; Supervision - AG, GC; Data Collection and/or Processing- GC, KV, YE, RU, BAK; Analysis and/or Interpretation - GC, KV; Literature Review GC, KV, YE, RU, BAK; Writing - GC; Critical Review - AG.

Conflict of Interest: The authors have not reported a conflict of interest.

Financial Disclosure: There is no financial support in this study.

\section{References}

1. Heininger U, Seward JF. Varicella. Lancet 2006;368:1365-6.5

2. Dinleyici EC, Kurugol Z, Turel O, Hatipoğlu N, Devrim I, Agin H, et al. The epidemiology and economic impact of varicella-related hospitalizations in Turkey from 2008 to 2010: a nationwide survey during the pre-vaccine era (VARICOMP study). Eur J Pediatr 2012;171:817-25.

3. Trojian TH, Lishnak TS, Heiman D. Epididymitis and orchitis: an overview. Am Fam Physician 2009;79:583-7.
4. McKay DG, Margaretten W. Disseminated intravascular coagulation in virus diseases. Arch Intern Med 1967;120:129-51.

5. Gkentzis A, Lee L. The aetiology and current management of prepubertal epididymitis. Ann R Coll Surg Engl 2014;96:181-3.

6. Cappele O, Liard A, Barret E, Bachy B, Mitrofanoff P. Epididymitis in children: is further investigation necessary after the first episode? Eur Urol 2000;38: 627-30.

7. Leung AK, Robson WL. Orchitis as a complication of chickenpox. Br J Gen Pract 1991;41:130.

8. Kaul A, Sharma RK, Bhadhuria D, Gupta A, Prasad N. Chickenpoxinfection after renal transplantation. Clin Kidney J 2012;5:203-6.

9. Hunt MNS. Br J Gen Pract Nov.1990 p: 480, letter.

10. Liu HC, Tsai TC, Chang PY, Shih BF. Varicella orchitis: report of two cases and review of the literature. Pediatr Infect Dis J 1994;13:748-50.

11. Wesselhoeft $C$, Pearson CM. Orchitis in the course of severe chicken pox with pneumonitis, followed by testicular atrophy. N Engl J Med 1950;242:651-2.

12. Ormiston G. Orchitis as a complication of chicken-pox. Br Med J 1953;1:1203-4.

13. Turner RB. Orchitis as a complication of chickenpox. Pediatr Infect Dis J 1987;6:489. 